Pirineos, 151-152: 43 a 72, JACA; 1998

\title{
DIVERSITY OF SOIL ORGANISMS IN ALPINE AND ARCTIC SOILS IN EUROPE. REVIEW AND RESEARCH NEEDS
}

\author{
GABRIELE BROLL \\ Institute of Landscape Ecology, University of Münster. Robert-Koch-Str. 26, D-48149 \\ Münster, Germany, e-mail:brollg@uni-muenster.de
}

SUMMARY.- The diversity of soil organisms and soil ecological processes in different mountain regions of Europe are reviewed. Detailed taxonomic studies on soil organisms have been made in the Alps and in Northern Europe since the end of the last century, however, there is a paucity of data from Southern Europe. Future studies could include the re-sampling of historic study sites to assess if there has been a change in the soil fauna and microorganisms. The role of key abiotic processes such as cryoturbation should be quantified and further research should focus on identifying indicator organisms, keystone species and functional groups. In addition, studies on soil organic matter and particularly on humus forms, the products of soil ecological processes should be encouraged. Ecotones, where the influence of spatial heterogeneity on soil biodiversity is likely to be particularly pronounced, appear to be the most rewarding for such studies.

RÉSUMÉ.-La diversité des organismes du sol et les différents processus écologiques ayant lié dans les diverses régions de montagne en Europe sont détaillés. Des études approfondies sur la taxonomie des organismes du sol ont été developpées dans les Alpes et en Europe du Nord depuis la fin du siècle dernier, mais par contre il y a peu de données sur l'Europe du Sud. Dans l'avenir on pourrait re-étudier les sites bien connus de façon à savoir s'il y a eu de changements dans la faune et les microorganismes du sol. Il faudrait quantifier le rôle des processus abiotiques comme la cryoturbation, identifier les organismes indicateurs, les espèces-clé et les groupes fonctionnels. Il est aussi indispensable de développer les études sur la matière organique et en particulier les types d'humus, en tant que résultat des processus écologiques du sol. Les écotones, dans lesquels l'influence de l'heterogeneité spatiale sur la biodiversité $d u$ sol est particulièrement prononcée, semblent les plus pertinents pour de telles études.

RESUMEN.- Presentamos una revisión de los organismos del suelo y de los procesos ecológicos edáficos en las diferentes zonas de montaña de Europa. En los 


\begin{abstract}
Alpes y en Europa septentrional se han llevado a cabo estudios taxonómicos detallados sobre los organismos del suelo, pero tenemos pocos datos de Europa meridional. De cara al futuro se tendrian que volver a muestrear los parajes que dieron lugar a estudios clásicos, de modo que se pudiera comprobar si ha habido cambios en la edafofauna y en los microorganismos. Convendria también cuantificar los procesos abióticos como la crioturbación y atender a la identificación de organismos indicadores, especies-clave y grupos funcionales. Hay que apoyar además los estudios sobre la materia orgánica del suelo, particularmente los tipos de humus, como productos que son de los procesos ecológico-edáficos. En todos esos estudios se muestran prometedores los ecotonos, por cuanto la influencia de la heterogeneidad espacial en la biodiversidad edáfica parece primordial.
\end{abstract}

Keywords: Soil organisms, biodiversity, alpine and arctic Europe.

\title{
1. Biodiversity
}

Conservation of biodiversity has become increasingly topical (e.g. GROOMBRIDGE, 1992; HUSTON, 1994; HEYWOOD \& WATSON, . 1995; CATIZZONE et al., 1998). From an ecological perspective research on biodiversity is of prime interest in relation to ecosystem functioning (e.g. SCHULZE \& MOONEY, 1993; NAEEM et al., 1994; DI CASTRI \& YOUNÉS, 1996) and especially to the stability of ecosystems (WALKER, 1989; BERENDSE, 1993; GREENLAND \& SZABOLCS, 1994; CHERNOV, 1995). Investigations on biodiversity are nowadays often related to sustainability (e.g. HAWKSWORTH, 1991) or global climate change (BOER \& KOSTER, 1992; CHAPIN et al., 1992; HOLTEN et al., 1993; SOLBRIG et al., 1994; WATSON et al., 1996).

Most recent studies on arctic and alpine biodiversity have been concerned with plant diversity (e.g. CHAPIN \& KÖRNER, 1995) focusing on North America and Russia, where arctic and sub-arctic ecosystem research has had a long tradition (e.g. BEHAN-PELLETIER, 1993; HERSHEY et al., 1995; HOBBIE, 1995; PASTOR, 1995; SCHIMEL, 1995). Relatively little studied have been soil biochemical cycling and interrelationships between soil and plants in alpine (MEYER \& THALER, 1995; PASTOR, 1995) or (sub-) arctic areas (BEHAN-PELLETIER \& BISSETT, 1992; CALLAGHAN \& JONASSON, 1995; CALLAGHAN et al., 1995) in Europe. It would be relatively simple to initiate more research in the specialised field of soils and biodiversity because of the broad background in European mountain research with respect to global change and specified future research needs (BENISTON, 1994;.GUISAN et al., 1995; PRICE, 1995) 


\section{Soil ecology and soil organisms}

In this paper soil ecology is defined as the science of interactions among soil biota and between the soil biota and the abiotic environment. Soil ecological research focuses on the interdependence between soil physical and chemical properties and soil organisms, soil organic matter, decomposition, nutrient cycling, and interactions in the rhizosphere. Soil organisms and soil ecological processes respond very sensitively to human disturbances therefore they should be considered in recommendations on environmental change (GISI et al., 1997).

Only those soil organisms which play an important role in ecosystem functioning have been taken into account. Apart from microorganisms, these include the following invertebrate groups: lumbricidae, enchytraeidae, collembola, acari, diplopoda, isopoda, nematoda, protozoa and insect larvae. Some small mammals, especially burrowing rodents, may influence soil properties in alpine areas in many ways (e.g. HOLE, 1981; HUNTLY \& INOUYE, 1988; MEADOWS \& MEADOWS, 1991; BASSANO et al., 1992; CORTINAS \& SEASTEDT, 1996). The interactions between these animals and the vegetation have been investigated (e.g. ANDERSSON \& JONASSON, 1986; HANSSON, 1987; MOEN et al., 1993; HERRERO et al., 1994) and an important example is rodent damage to tree seedlings in mountain forests where the regeneration of a whole ecosystem may be affected. Rodents are also important in influencing soil ecological processes in Fennoscandia where many studies have been made on them (e.g. HENTTONEN, 1995). Despite the important role mammals play in soils of arctic and alpine areas they could not be included in this review.

In arctic and alpine regions many soil organisms are adapted to the extreme environmental conditions (viz. MANI, 1968; CALLAGHAN et al., 1992) and both psychrophilic microorganisms (e.g. HERBERT \& CODD, 1986) and soil invertebrates have developed special adaptations to survive (e.g. BRINCK, 1974; WALLWORK, 1976b; BLOCK, 1990; SØMME, 1995). For example, glycerol is a very important cryoprotectant for the soil mesofauna (COULSON et al., 1995). Another example is the existence of subnivean food chains (e.g. AITCHISON, 1984). The activity of microorganisms below zero temperatures has long been underestimated (e.g. CLEIN \& SCHIMEL, 1995), although some workers in the Alps have reported cold hardiness and tolerance to desiccating conditions by collembola (BLOCK \& ZETTEL, 1980) and millipedes (MEYER \& EISENBEIS, 1985). 
PIRINEOS 151-152

\section{Diversity of soil organisms}

Although a large body of literature on biodiversity exists, comparatively few investigations have been carried out on biodiversity of soil organisms to date (e.g. LEE, 1991, 1994; BERNARD, 1992 for nematodes; TRÜPER, 1992 for prokaryotes; HAWKSWORTH \& COLWELL, 1992; FRECKMAN, 1994; SOMBROEK, 1994). There is a paucity of data at the species level (e.g. GROOMBRIDGE, 1992; HAWKSWORTH \& RITCHIE, 1993); only about $11 \%$ of estimated bacteria species in the world are described, and the figure for fungi is only $5 \%$ (HAWKSWORTH, 1991). In extreme environments such as those in alpine and arctic areas many species are unknown (GROOMBRIDGE, 1992). Many new methods (e.g. molecular biological methods) have been developed for identifying microorganisms that are also available for studying microorganisms in alpine and arctic environments.

The diversity of soil organisms is of great importance for ecosystem functioning.(SCHULZE \& MOONEY, 1993; ALLSOPP et al., 1995; COLLINS et al., 1995; LAVELLE et al., 1995; DI CASTRI \& YOUNÉS, 1996; HEAL et al., 1996). Most of the reported studies have been made in relation to sustainable agriculture (HAWKSWORTH, 1991; GREENLAND \& SZABOLCS, 1994) and natural ecosystems have been of less interest (MOLDENKE et al., 1994). A diverse array of soil organisms is necessary for decomposition and biogeochemical cycles in every ecosystem, natural or managed (LEE, 1991; BEARE et al., 1995). The functioning of nutrient cycles is a good indicator of ecosystem integrity and stability (BERENDSE, 1993; SCHULZE \& MOONEY, 1993; COLEMAN et al., 1994). Earlier studies have acknowledged the importance of the diversity of the soil fauna and its role in ecosystem functioning (e.g. WALLWORK, 1976a; DANKS, 1981), but perhaps overlooked the importance of the diversity of microorganisms.

There is an important connection between the diversity of soil organisms and climate change (COLEMAN et al., 1992; DANKS, 1992; SØMME, 1993). An increase in temperature could have a pronounced effect on the carbon and nutrient cycles in alpine and arctic regions (CHAPIN et al., 1992). It is believed that currently these regions act as carbon sinks, but they could become carbon sources through for example increased mineralisation rates (HEAL et al., 1998). The impacts on soil microbial activity could therefore be better predicted if the diversity of soil organisms and soil ecological processes in these extreme environments were better known. 


\section{Soil ecological processes and the diversity of soil organisms in the different mountain regions of Europe}

In the alpine regions of Central Europe there has been a long tradition of research on soil organisms (viz. PERTY, 1849) and there is a large body of literature on the soil fauna in Austria and Switzerland dating back to the turn of the $20^{\text {th }}$ century. The collembola and myriapoda (e.g. VERHOEFF, 1896; CARL, 1899; DIEM, 1903; HANDSCHIN, 1919; ATTEMS, 1949; JANETSCHEK, 1949; GISIN, 1957; SCHWEIZER, 1961) and lumbricides (e.g. ROSA, 1887; RIBIAUCOURT, 1896; BRETSCHER, 1900) have especially been well treated. More recently, a large number of ecological studies have investigated the interactions between vegetation and soil mesofauna including changes along altitudinal gradients (e.g. JAHN, 1960; CHRISTANDL-PESKOLLER \& JANETSCHEK, 1976; NURMINEN, 1977; THALER et al., 1978; LIENHARD, 1980; MEYER, 1981, 1985; SCHATZ, 1981; TROGER, 1981; REUTIMANN, 1987; JANETSCHEK, 1993; LESER, 1994). Investigations on mesofauna are still being carried out (e.g. THALER et al., 1993) and MEYER \& THALER (1995) have recently reported their diversity in alpine regions. Earthworms are important representatives of the soil macrofauna have been studied by SISTANI (1980), KÜBELBÖCK \& MEYER (1981), ZICSI (1981) and CUENDET (1987). Austrian workers have been outstanding in their treatment of the soil microfauna (BERGER et al., 1985; FOISSNER, 1985; FOISSNER \& PEER, 1985) including nematodes (GERBER, 1985). Reviews on alpine areas along with the results of the Austrian MAB programme «Hohe Tauern» include those by.FRANZ $(1975,1980,1981)$ and SCHALLER's (1994) general overview on soil zoology in Austria.

Many studies of soil microbiology have been carried out in Austria including an early study by GAMS (1959). One of the most important sources of knowledge in this special field has been the above mentioned MAB projects, where most of the microbiological investigations were made by Schinner and co-workers. Their results on abandoned pastures and along altitudinal gradients were summarised by CERNUSCA $(1978,1989)$. In addition to taxonomic identification and quantification of soil microorganisms, the following have been characterised: processes of the carbon and the nitrogen cycles (REHDER \& SCHÄFER, 1978; HAUNOLD et al., 1980; BRUNNER \& BLASER, 1989; HACKL et al., 1995) and decomposition rates (e.g. SCHINNER, 1982; GSTRAUNTHALER \& SCHINNER, 1989; SCHINNER \& GURSCHLER, 1989; SCHINNER et al., 1989). The investigated alpine soils had a relatively low number of fungi species, high cell counts of bacteria, actinomycetes and yeasts. From soil respiration measurements it has been concluded that soil microorganisms 
were adapted to low temperatures in the alpine zone. Decomposition has been reported to be most intensive after snow melt in early summer, whilst tends to be followed by a decrease in microbial activity during summer because of low soil moisture. The initial studies on soil respiration at abandoned alpine sites by CERNUSCA et al. (1978) have later been extended to include the relationship between soil respiration and secondary succession in the Italian Alps (INTEGRALP project, TAPPEINER \& CERNUSCA, 1994). Mycorrhizae have also been studied in the Austrian MAB projects. Ericoid mycorrhiza in the dwarf shrub heath and the vesicular-arbuscular mycorrhiza of the grass and herbaceous species in grass heath communities have been shown to be important for plant nutrition with the ericoid infection intensity decreasing with altitude (HASELWANDTER \& READ, 1980; HASELWANDTER, 1989). In alpine areas mycorrhizal infection is of special importance for re-afforestation projects (ALLEN et al., 1987; GÖBL, 1994). Changing abiotic site factors and their influence on soil microorganisms along altitudinal gradients have also been considered (DUTZLER-FRANZ, 1981), however it has been difficult to demonstrate changes along an altitudinal gradient as they may easily be offset by microtopographic heterogeneity (SCHINNER, 1983; McCOY, 1990; RANGGER et al.; 1994).

In Germany, there have only been few studies on the soil fauna in alpine soils (e.g. TOPP, 1975; BOLLER, 1986; GEMESI et al., 1995; SKAMBRACKS, 1996). Most of the soil ecological studies in the German Alps have been carried out in the Berchtesgaden National Park as part of a MAB project (HABER et al., 1990). Humification processes, in particular chemical characterisation of humic substances (BOCHTER \& ZECH, 1985; KÖGEL, 1987; KÖGEL et al., 1988), have been of primary interest and investigations focused more on the products of soil ecological processes, including humus forms (BOCHTER, 1988), than on the soil organisms themselves.

Studies of soil fauna, lumbricides in particular, and soil ecology have had a long tradition in France (e.g. BOUCHÉ, 1995; LAVELLE et al., 1995). In the Alps, however, the main emphasis has been on microbial activity, especially nitrogen mineralisation (BOUDOT \& CHONE, 1985; GOURBIÈRE, 1986; TOSCA, 1986; PORNON \& DOCHÉ, 1994).

There is a paucity of data on soil ecological processes in the southern part of the Alps and the Iberian Peninsula. There have been some recent ecological investigations on altitudinal gradients in Italy (e.g. DI CASTRI, 1973; BRANDMAYR et al., 1995) after earlier studies on soil fauna (e.g. VERHOEFF, 1932). SIMON et al. (1994) have reported their work on soil organic matter in the Sierra Nevada, Spain.

There is a long list of publications on soil organisms from the eastern part of Europe, however, most of them were published locally. Taxonomic and 
DIVERSITY OF SOIL ORGANISMS IN ALPINE AND ARCTIC SOILS IN EUROPE

ecological investigations have been reported for the Carpathians (KURCHEVA, 1972; RUSEK et al., 1975; STRIGANOVA, 1975; POPOVICI, 1984; POP, 1987; NOSEK, 1986; HARSIA, 1995; POP \& VASU, 1995), the Caucasus (GHILAROV, 1979; STRIGANOVA \& MAZANTSEVA, 1979; SAMEDOV \& BABABEKOVA, 1980) and some other regions such as the Pieniny mountains (WASILEWSKA, 1974). Recently, the influence of pollution on mountain forest soils has become of special interest (RUZICKA \& ZACHARDA, 1994; BOHAC \& FUCHS, 1995; CHALUPSKY, 1995). The number of studies for the southeastern part of Europe e.g. in Greece is few (NAKOS, 1984; LEGAKIS, 1986).

In contrast, there is a large body of literature in Northern Europe. One of the oldest study areas for soil zoologists has been the Svalbard (e.g. RÖMER \& SCHAUDINN, 1900; NURMINEN, 1965a; RÜPPELL, 1968; BENGSTON et al., 1974; COULSON et al., 1995; HODKINSON et al., 1996; 1998). Recent years have seen some publications on interactions between soil fauna, microorganisms and abiotic site conditions (e.g. SVEUM, 1986; VÄRE et al., 1992; WÜTHRICH, 1994; WÜTHRICH et al., 1994; DÖBELI, 1995; HODKINSON et al., 1996) including global change aspects (HODKINSON et al., 1998). In addition to Svalbard, the mountains of Lapland and the Scandinavian mountains have been the main areas for studies on soil organisms in Scandinavia (TRÄGARDH, 1910; BRINCK \& WINGSTRAD, 1949; DALENIUS, 1960; NURMINEN, 1965b; CADWALLADR, , 1969; ' SENICZAK \& PLICHTA, 1978; HAGVAR, 1982; KOPONEN, 1984), especially at the IBP sites (FJELLBERG, 1975; HAGVAR \& OSTBYE, 1975; SOLHØY, 1975). Many soil zoologists working in Finnish Lapland have focused on soil mesofauna (e.g. KOPONEN \& OJALA, 1975; SOLHØY \& KOPONEN, 1981). Numerous studies have dealt with microorganisms and decomposition (BERG et al., 1975; CLARHOLM et al., 1975; ROSSWALL et al., 1975; MOSIMANN, 1985; MÜLLER et al., 1994) and some investigated the impact of acid rain (KYTÄVIITA et al., 1990; NEUVONEN \& SUOMELA, 1990). Co-operative projects between Finnish and Russian ecologists have researched heavy metal pollution on the Kola Peninsula (GILYASOVA, 1993; KONEVA, 1993; EVDOKIMOVA, 1995). In Greenland and Iceland taxonomic studies have been made for long (e.g. JÖRGENSEN, 1934; SELLNICK, 1940), but little experimental research on soil organisms has been reported (e.g. RICHARD \& HARMSTON, 1972).

\section{Research needs}

Many research recommendations have been made about biodiversity in a changing climate (e.g.: SOLBRIG et al., 1994) and about soils and climate 
change (ARNOLD et al., 1990; BOUWMAN, 1990; COLEMAN et al., 1992; ROUNSEVELL \& LOVELAND, 1994). Some of these concern priorities for further research on biodiversity in mountain areas (e.g. CHEMINI; 1994) and there are many more on mountain research in general (e.g. OZENDA \& BOREL, 1991; IVES, 1992; UNCED, 1992). Some of them, however, are reiterations of topics discussed for the past 20 years (viz. MÜLLERHOHENSTEIN, 1974; UNEP, 1980), especially in relation to the stability of alpine ecosystems (GIGON, 1983; IVES \& MESSERLI, 1984).

The published recommendations for priority research on biodiversity apply particularly to soil ecology. Comparisons between the results of detailed taxonomic studies on soil organisms made in the late 19th and early 20th century and those of current research have shown a loss of species in several mountain regions (ALPNET, unpublished). However, this kind of comparison (regarding $\alpha$-diversity) is fraught with uncertainties because of the large number of organisms involved and because there are still many undescribed species. Research has begun to focus on finding indicator soil organisms (HAWKSWORTH, 1992; FOISSNER, 1994) and keystone species (SCHULZE \& MOONEY, 1993), but rarely in mountain areas. Important types of keystone species are earth movers which affect soil ecological processes by bioturbation. Decomposers and mycorrhizae are also important types of keystone species for nutrient cycling. Abiotic agents which cause physical disturbances such as cryoturbation, contribute to key proceses which have a bearing on the diversity of soil organisms. In the lowlands and in low mountain areas lumbricides are the most important indicator organisms (e.g. GLASSTETTER, 1991) and they also play an important role in high mountain ranges (e.g. POP, 1987; POP \& VASU, 1995; SKAMBRACKS, 1996), with the exception of northern Europe with low temperature.

A right step would be to identify species ecotypes and functional groups (SINNIGE et al., 1992; ZVYAGINTSEV et al., 1992; SCHULZE \& MOONEY, 1993) and to study below-ground food webs in mountain soils. It would also be desirable to understand the ability of species to invade after perturbation and how this affects the habitat. Redundancy aspects should also be taken into account (SCHULZE \& MOONEY, 1993; EUROPEAN COMMUNITY, 1994). Until now, such studies in soil ecology have more or less been restricted to agro-ecosystems (e.g. ANDRÉN et al., 1995). There is a considerable scope for experimentation there.

With regard to mineralisation and humification, research should focus on meso- and microhabitats of microorganisms in soil organic matter. Also, this would help to provide recommendations on how to protect humus on mountain slopes, particularly where there is intensive erosion. Another issue 
is the rhizosphere, where the role of mycorrhizae in alpine and arctic areas should be more intensively investigated.

Soil type, including humus form, is an important tool to characterise habitats. The influence of abiotic site factors such as texture and $\mathrm{pH}$, on soil organisms and their activity has been widely studied. However, the role of soil organisms in pedogenesis is often neglected today, but had previously been studied by KUBIENA (1943) and KÜHNELT (1944). They have shown the impact of lumbricides on the genesis of mull rendzina soils (see MARTINUCCI \& SALA, 1979). Some related studies have also been conducted in alpine areas by FREI (1944), ZÖTTL (1965), GILOT \& DOMMERGUES (1967), GRACANIN (1970) and SZABÓ (1974). The description of the humus form to characterise habitats for soil organisms is very useful because the humus form is the result of the activity of organisms. Such work has to date been made in forest soils, the results of which only apply to a limited extent to subalpine and alpine situations (F. EDNORZ et al., unpublished). In mountain regions, natural and managed grasslands cover large areas (CERNUSCA, 1991) and an improved classification of grassland humus forms would help classify habitats for soil organisms (BROLL \& BRAUCKMANN, 1994).

In addition to elevational gradients (e.g. McCOY, 1990), the spatial heterogeneity in mountain areas - especially at the ecotone level- is of importance for soil ecological processes (JENNY, 1980; NEUWINGER, 1987; HOLTMEIER \& BROLL, 1992; BROLL, 1994; BROLL \& HOLTMEIER, 1994; HOLTMEIER, 1994; KEPLIN, 1994; ADAM, 1995; BEDNORZ et al., 1999). A further step in understanding ecological dynamics at the ecosystem and landscape scales (GRABHERR, 1994; HUSTON, 1994; DUELLI, 1995) has already been taken in the Arctic interdisciplinary research conducted in North America (e.g. BLISS et al., 1981; SVOBODA \& FREEDMAN, 1992; REYNOLDS \& TENHUNEN, 1996). This should be sought in Europe. New initiatives on soil ecological research in Europe could build on the knowledge available from MAB and IBP programmes and use their sites (e.g. ROSSWALL \& HEAL, 1975; WIELGOLASKI, 1975a; 1975b; FRANZ, 1981; CERNUSCA, 1989). In this respect the Natural Environmental Research Council (U.K.) research programme on «Soils and Biodiversity» is particularly welcome.

In line with general recommendations for biodiversity research, the monitoring of permanent plots could be combined with using existing longterm sites such as those of ITEX. Applied studies on the impact of recreation and tourism in mountain areas (e.g. MOSER et al., 1987; JANETSCHEK et al., 1987; MEYER, 1993; TROCKNER \& KOPESZKI, 1994) should have a soil ecological component in the future. Current soil ecological research uses many new methods, e.g. mesocosm studies and molecular biological 
methods for determination of microorganisms, which could be applied in alpine and arctic areas, also (ROBINSON \& WOOKEY, 1997). New classification approaches in soil ecology should be developed to achieve wider ecological applications (e.g. FABER, 1991; SINNIGE et al., 1992; BEARE et al., 1995).

\section{References}

ADAM, M. (1995). Die Übergangszone von Buchen- und Fichtenwald in den nördlichen Kalkalpen - klimatische, edaphische und vegetationskundliche Aspekte dargestellt am Beispiel des Tamina- und Calfeisentales (SG/GR). Dissertation, Zürich.

AITCHISON, C.W. (1984). A possible subnivean food chain. In: Winter Ecology of Small Mammals (Ed. J.F. Merritt). Special Publication of the Carnegie Museum of Natural History, 10, pp. 363-372, Pittsburgh.

ALLEN, E.B., CHAMBERS, J.C., CONNOV, K.F., ALLEN, M.F. \& BROWN, R.W. (1987). Natural reestablishment of mycorrhizae in disturbed alpine ecosystems. Arctic and Alpine Research, 19: 11-20.

ALLSOPP, D., COLWELL, R.R. \& HAWKSWORTH, D.L. (Eds.) (1995). Microbial Diversity and Ecosystem Function. Proceedings of the IUBS/IUMS Workshop held at Egham, UK, 10-13 August 1993 in support of the IUBS/UNESCO/SCOPE «Diversitas» Programme. CAB International, 482 pp., Wallingford.

ANDERSON, M. \& JONASSON, S. (1986). Rodent cycles in relation to food resources on an alpine heath. Oikos, 46: 93-106.

ANDRÉN, O., BENGTSSON, J. \& CLARHOLM, M. (1995). Biodiversity and species redundancy among litter decomposers. In: The Significance and Regulation of Soil Biodiversity (Eds. H.P. Collins, G.P. Robertson \& M.J. Klug), Selected Papers from an Int. Symposium on Soil Biodiversity, Michigan State Univ., May 3-6 1993. Kluwer, pp. 141-151, Dordrecht.

ARNOLD, R.W., SZABOLCS, I. \& TARGULIAN, V.O. (1990). Global Soil Change. Report of an IIASA-ISSS-UNEP Task Force on the Role of Soil in Global Change. International Institute for Applied Systems Analysis, Laxemburg, 110 pp., Austria.

ATTEMS, C. (1949). Die Myriapodenfauna der Ostalpen. Sitzungsberichte der Akademie der Wissenschaften Wien, mathematisch-naturwissenschaftliche Klasse, 158 (1/2): 79-153.

BASSANO, B., DURIO, P., GALLO ORSI, U., \& MACHI, E. (Eds.) (1992). Proceedings of the 1st International Symposium on Alpine Marmot and gen. Marmota. Turin, Italy. 
DIVERSITY OF SOIL ORGANISMS IN ALPINE AND ARCTIC SOILS IN EUROPE

BEARE, M.H., COLEMAN, D.C., CROSSLEY Jr., D.A., HENDRIX, P.F. \& ODUM, E.P. (1995). A hierarchical approach to evaluating the significance of soil biodiversity to biogeochemical cycling. Plant and Soil, 170: 5-22.

BEDNORZ, F., REICHSTEIN, M. \& BROLL, G. (1999). Die mikrobielle Biomasse der Böden im Waldgrenzökoton am Stillberg (Dischmatal bei Davos/Schweiz). Mitteilungen der Deutschen Bodenkundlichen Gesellschaft, 89: 205-208.

BEHAN-PELLETIER, V.M. (1993). Diversity of soil arthropods in Canada: systematic and ecological problems. Memoires of the Entomological Society of Canada, 165: 11-50.

BEHAN-PELLETIER, V.M. \& BISSETT, B. (1992). Biodiversity of nearctic soil arthropods. Canadian Museum of Nature, 2: 5-14.

BENISTON, M. (Ed.) (1994). Mountain Environments in Changing Climates. Routledge, pp. 461, London.

BENGSTON, S.A., FJELLBERG, A. \& SOLHØY, T. (1974). Abundance of tundra arthropods in Spitsbergen. Entomol. Scanol., 5: 137-142.

BERENDSE, F. (1993). Ecosystem stability, competition, and nutrient cycling. In: Biodiversity and Ecosystem Function (Eds. E.-D. Schulze \& H.A. Mooney), Ecological Studies, 99. Springer-Verlag, pp. 409-431, Heidelberg.

BERG, B., KÄRENLAMPI, K. \& VEUM, A.K. (1975). Comparisons of decomposition rates measured by means of cellulose. In: Fennoscandian Tundra Ecosystems. Part 1 Plants and Microorganisms (Ed. F.E. Wielgolaski), Ecological Studies, 16. Springer-Verlag, pp. 261-267, Heidelberg.

BERGER, H., FOISSNER, W. \& ADAM, H. (1985). Protozoologische Untersuchungen an Almböden im Gasteiner Tal (Zentralalpen, Österreich): IV. Experimentelle Studien zur Wirkung der Bodenverdichtung auf die Struktur der Testaceen- und Ciliatentaxozönose. In: Beiträge zu den Wechselbeziehungen zwischen den Hochgebirgsökosystemen und dem Menschen (Ed. H. Franz), Veröffentlichungen des Österreichischen MaB-Programms, 9. Universitätsverlag Wagner, pp. 97-112, Innsbruck.

BERNARD, E.C. (1992). Soil nematode biodiversity. Biology and Fertility of Soils, 14: 99-103.

BLISS, L.C., HEAL, O.W. \& MOORE, J.J. (Eds.) (1981). Tundra Ecosystems: A Comparative Analysis. Cambridge University Press, 813 pp., Cambridge.

BLOCK, W. (1990). Cold tolerance of insects and other arthropods. Philosophical Transactions of the Royal Society of London, Series B, 326: 613-633.

BLOCK, W. \& ZETTEL, J. (1980). Cold hardiness of some alpine Collembola. Ecological Entomology, 5: 1-9.

BOCHTER, R. (1988). Böden naturnaher Bergwaldstandorte auf carbonatreichen Substraten. Beiträge zur Genese, Ökologie und Systematik. Dissertation 
Universität Bayreuth. Nationalpark Berchtesgaden Forschungsberichte, 6 . Plenk, pp. 212, Berchtesgaden.

BOCHTER, R. \& ZECH, W. (1985). Organic compounds in cryofolists developed on limestone under subalpine coniferous forest, Bavaria. Geoderma, 36: 145-157.

BOER, M. \& KOSTER, E. (Eds.) (1992). Greenhouse Impact on Cold-Climate Ecosystems and Landscapes. Catena-Supplement, 22: Catena-Verlag, 151 pp., Cremlingen-Derstedt.

BOHÁC, J. \& FUCHS, R. (1995). The effect of air pollution and forest decline on epigeic staphylinid communities in the Giant Mountains. Acta Zoologica Fennica, 196: 311-313.

BOLLER, F. (1986). Diplopoden als Streuzersetzer in einem Lärchenwald. Nationalpark Berchtesgaden, Forschungsbericht, 9. Plenk, 88 pp., Berchtesgaden.

BOUCHÉ, M.B. (1995). Modern ecology methods and means allowing broadcasting and application of the roles of soil fauna knowledge. Acta Zoologica Fennica, 196: 206-211.

BOUDOT, J.P. \& CHONE, T. (1985). Internal nitrogen cycling in two humicrich acidic soils. Soil Biology and Biochemistry, 17: 135-142.

BOUWMAN, A.F. (Ed.) (1990). Soils and the Greenhouse Effect. Proceedings of the International Conference: Soils and the Greenhouse Effect. Wiley, 575 pp:; Chichester.

BRANDMAYR, P., BERNADO, I., CAGNIN, M., MINGOZZI, T. \& PIZOLOTTO, R. (1995). Biodiversita multitaxon in Calabria su scale locale, regionale ed ecologio-paesaggistica. P. S. CNR «Clima, ambiente e territori nel Mezzogiorno». Amalfi.

BRETSCHER, K. (1900). Über die Verbreitungsverhältnisse der Lumbriciden in der Schweiz. Biologisches Zentralblatt, 20: 703-717.

BRINCK, P. (1974). Strategy and dynamics of high altitude faunas. Arctic and Alpine Research, 6: 107-116.

BRINCK, P. \& WINGSTRAND, K.G. (1949). The Mountain Fauna of the Virihaure area in Swedish Lapland. I. General Account. Lunds Univ. Arsbok. N. F. 45. Lund.

BROLL, G. (1994). Influence of the soil mosaic on biodiversity at heath sites in the European subarctic. Transactions 15th World Congress of Soil Science (Mexico), 4a: 220-231.

BROLL, G. \& BRAUCKMANN, H.-J. (1994). Humusformen und Regenwurmfauna zweier Grünlandbrachen in Südwestdeutschland. Mitteilungen der Deutschen Bodenkundlichen Gesellschaft, 74: 49-52. 
BROLL, G. \& HOLTMEIER, F.-K. (1994). Die Entwicklung von Kleinreliefstrukturen im Waldgrenzökoton der Front Range (Colorado, USA) unter dem Einfluß leewärts wandernder Ablegergruppen. Erdkunde, 48: 48-59.

BRUNNER, W. \& BLASER, P. (1989). Mineralization of soil organic matter and added carbon substrates in two acidic soils with high nonexchangeable Aluminium. Zeitschrift für. Pflanzenernährung und Bodenkunde, 152: 367-372.

CADWALLADR, D.A. (1969). On the soil inhabiting Collembola (Insecta) and Oribatei (Acarina) of the Olderfjord Region in North Norway. Astarte, 2: 7-25.

CALLAGHAN, T.V. \& JONASSON, S. (1995). Implications for changes in arctic plant biodiversity from environmental manipulation experiments. In: Arctic and. Alpine Biodiversity: Patterns, Causes and Ecosystem Consequences (Eds. F.S. Chapin III \& C. Körner), Ecological Studies, 113. Springer-Verlag, pp. 151-166, Heidelberg.

CALLAGHAN, T.V., SONESSON, M. \& SØMME, L. (1992). Responses of terrestrial plants and invertebrates to environmental change at high latitudes. Philosophical Transactions of the Royal Society of London, Series B, 338: 279-288.

CALLAGHAN, T.V., OECHEL, W.C., GILMANOV, T., HOLTEN, J.I., MAXWELL, B., MOLAU, U., SVEINBJÖRRNSSONN, B. \& TYSON, M.J. (Eds.) (1995). Global Change and Arctic Terrestrial Ecosystems. Proceedings of Papers Contributed to the International Conference, 21-26 August 1993, Oppdal, Norway. European Commission Ecosystem Research Report, 10, 329 pp., Brussels.

CARL, J: (1899). Über Collembola der Schweiz. Revue Suisse de Zoologie, 6: 274-362.

CATIZZONE, M., LARSSON, T.-B. \& SVENSSON, L. (Eds.) (1998). Understanding Biodiversity - A Research Agenda Prepared by the European Working Group on research and Biodiversity (EWGRB). European Commission Ecosystem Research Report, 25., 118 pp., Luxembourg.

CERNUSCA, A. (1978). Ecological changes on abandoned alpine pastures. In: Ökologische Analysen von Almflächen im Gasteiner Tal (Ed. A. Cernusca), Veröffentlichungen des Österreichischen MaB-Hochgebirgsprogramms Hohe Tauern, 2. Universitätsverlag Wagner, pp. 17-27, Innsbruck.

CERNUSCA, A. (1989). Ecosystem research in the Austrian Centralalps (Hohe Tauern). In: Struktur und Funktion von Graslandökosystemen im Nationalpark Hohe Tauern. (Ed. A. Cernusca), Veröffentlichungen des Österreichischen MaB-Programms, 13. Universitätsverlag Wagner, pp. 587-625, Innsbruck.

CERNUSCA, A. (1991). Ecosystem research on grassland in the Austrian Alps and the Central Caucasus. In: Facets of Modern Ecology (Eds. G. Esser \& V. Overdiek), Elsevier, pp. 233-271, Amsterdam. 
CERNUSCA, A., DECKER, P. \& HAGER, J. (1978). Bestandes- und Bodenatmung im Bereich einer aufgelassenen Alm im Gasteiner Tal. In: Ökologische Analysen von Almflächen im Gasteiner Tal (Ed. A. Cernusca), Veröffentlichungen des Österreichischen MaB-Hochgebirgsprogramms Hohe Tauern, 2. Universitätsverlag Wagner, pp. 143-154, Innsbruck.

CHALUPSKY, J. (1995). Long-term study of Enchytraeidae (Oligochaeta) in man-impacted mountain forest soils in the Czech Republic. Acta Zoologica Fennica, 196: 318-320.

CHAPIN III, F.S., JEFFERIES, R.L., REYNOLDS, J.F., SHAVER, G.R., SVOBODA, J. \& CHU, E.W.'(1992). Arctic Ecosystems in a Changing Climate. An Ecophysiological Perspective. Academic Press, 469 pp., San Diego.

CHAPIN III, F.S. \& KÖRNER, C. (Eds.) (1995). Arctic and Alpine Biodiversity: Patterns, Causes and Ecosystem Consequences. Ecological Studies, 113. Springer-Verlag, 332 pp., Berlin.

CHEMINI, C. (1994). Biologische und landschaftliche Vielfalt. In: Aktionsplan Alpen-Forschung. Erste Ergebnisse des AlpenForums '94, 11.-16. September 1994 in Disentis (Ed. SANW), pp. 34-40, Bern.

CHERNOV, Y.I. (1995). Diversity of the arctic terrestial fauna. In: Arctic and Alpine Biodiversity: Pattern, Causes and Ecosystem Consequences (Eds. F.S. Chapin III \& C. Körner), Ecological Studies, 113. Springer-Verlag, pp. 8196, Heidelberg.

CHRISTANDL-PESKOLLER, H. \& JANETSCHEK, H. (1976). Zur Faunistik und Zoozönotik der südlichen Zillertaler Hochalpen. Alpin-Biologische Studien der Universität Innsbruck, 7: 1-134.

CLARHOLM, M., LID-TORSVIK, V. \& BAKER, J.H. (1975). Bacterial populations of some Fennoscandian tundra soils. In: Fennoscandian Tundra Ecosystems. Part 1 Plants and Microorganisms (Ed. F.E. Wielgolaski), Ecological Studies, 16. Springer-Verlag, pp. 251-260, Heidelberg.

CLEIN, J.S. \& SCHIMEL, J.P. (1995). Microbial activity of tundra and taiga soils at sub-zero temperatures. Soil Biology and Biochemistry, 27: 1231-1234.

COLEMAN, D.C., ODUM, E.P. \& CROSSLEY Jr., D.A. (1992). Soil biology, soil ecology and global change. Biology and Fertility of Soils, 14: 104-111.

COLEMAN, D.C., DIGHTON, J., RITZ, K. \& GILLER, K.E. (1994). Perspectives on the compositional and functional analysis of soil communities. In: Beyond the Biomass. Compositional and Functional Analysis of Soil Microbial Communities (Eds. K. Ritz, J. Dighton \& K.E. Giller), John Wiley \& Sons, pp. 261-271, Baffins Lane, Chichester.

COLLINS, H.P., ROBERTSON, G.P. \& KLUG, M.J. (Eds.) (1995). The Significance and Regulation of Soil Biodiversity. Selected Papers from an International Symposium on Soil Biodiversity, Michigan State University, May 3-6 1993. Kluwer, 292 pp., Dordrecht. 
CORTINAS, M.R. \& SEASTEDT, T.R. (1996). Short- and long-term effects of gophers (Thomomys talpoides) on soil organic matter dynamics in alpine tundra. Pedobiologia, 40: 162-170.

COULSON, S.J., HODKINSON, I.D., STRATHDEE, A.T., BLOCK, W., WEBB, N.R., BALE, J.S. \& WORLAND, M.R. (1995). Thermal environments of arctic soil organisms during winter. Arctic and Alpine Research, 27: 364-370.

CUENDET, G. (1987). Some aspects of the ecology of earthworms in the Alps. In: On Earthworms (Eds. A.M. Bonvicini Pagliai \& P. Omodeo), Selected Symposia and Monographs U.Z.I, 2, pp. 251-263, Mucchi, Modena.

DALENIUS, P. (1960). Studies of the Oribati (Acari) of the Torneträsk territory of Swedish Lapland. Oikos, 11: 80-124.

DANKS, H.V. (1981). Arctic Arthropods - A Review of Systematics and Ecology with Particular Reference to the North American Fauna. Entomological Society of Canada, 608 pp., Ottawa.

DANKS, H.V. (1992). Arctic insects as indicators of environmental change. Arctic, 45: 159-166.

DI CASTRI, F. (1973). Soil animals in latitudinal and topographical gradients of mediterranean ecosystems. In: Mediterranean Type Ecosystems (Eds. F. Di Castri \& H. Mooney), Springer-Verlag, pp. 171-190, Berlin.

DI CASTRI, F. \& YOUNÉS, T. (1996). Biodiversity, Science and Development. Towards a New Partnership. CAB International, 646 pp., Wallingford.

DIEM, K. (1903). Untersuchungen über die Bodenfauna in den Alpen. Jahrbuch der St. Gallener Naturwissenschaftlichen Gesellschaft, 1901-1902: 234-414.

DÖBELI, C. (1995). Zusammenhänge zwischen abiotischen Systemgrößen und ausgewählten biotischen Kompartimenten (Vegetation, Bodenrespiration) im hocharktischen Geoökosystem (Liefdefjorden, Nordwestspitzbergen). Materialien zur Physiogeographie, 18, 99 pp., Basel.

DUELLI, P. (1995). Biodiversität erhalten und fördern: Was sagt die ökologische Forschung dazu? In: Erhaltung der Biodiversität - eine Aufgabe für Wissenschaft, Praxis und Politik (Ed. Eidgenössische Forschungsanstalt für Wald, Schnee und Lawinen), p. 59, Birmensdorf.

DUTZLER-FRANZ, G. (1981). Einfluß der Temperatur auf die mikrobielle Aktivität einiger Böden aus der temperierten und hochalpinen Klimaregion. In: Bodenbiologische Untersuchungen in den Hohen Tauern 19741978 (Ed. H. Franz), Veröffentlichungen des Österreichischen MaBHochgebirgsprogramms Hohe Tauern, 4. Universitätsverlag Wagner, pp. 263-294, Innsbruck.

EUROPEAN COMMUNITY (1994). Biodiversity and Ecosystem Function in a European Perspective. An EC/Diversitas Workshop, 11.-13. July 1993 at Wye College. University of London, 15 pp., London. 
EVDOKIMOVA, G.A. (1995). Effects of pollution on microorganism biodiversity in arctic ecosystems. In: Global Change and Arctic Terrestrial Ecosystems. Proceedings of Papers Contributed to the International Conference, 21-26 August 1993, Oppdal, Norway. (Eds. T.V. Callaghan, W.C. Oechel, T. Gilmanov, J.I. Holten, B. Maxwell, U. Molau, B. Sveinbjörrnssion \& M.J. Tyson), European Commission Ecosystem Research Report, 10, pp. 315-320, Brussels.

FABER, J.H. (1991). Functional classification of soil fauna: a new approach. Oikos, 62: 110-117.

FJELLBERG, A. (1975). Organization and dynamics of Collembola populations on Hardangervidda. In: Fennoscandian Tundra Ecosystems. Part 2 Animals and Systems Analysis (Ed. F.E. Wielgolaski), Ecological Studies, 17. Springer-Verlag, pp. 73-79, Heidelberg.

FOISSNER, W., (1985). Protozoologische Untersuchungen an Almböden im Gasteiner Tal (Zentralalpen, Österreich). III. Struktur und Dynamik der Testaceen- und Ciliatentaxozönose. In: Beiträge zu den Wechselbeziehungen zwischen Hochgebirgsökosystemen und dem Menschen (Ed. H. Franz), Veröffentlichungen des Österreichischen MaB-Programms, 9. Universitätsverlag Wagner, pp. 66-95, Innsbruck.

FOISSNER, W. (1994). Soil protozoa as bioindicators in ecosystems under human influence. In: Soil Protozoa (Ed. J.F. Darbyshire), CAB International, pp. 147-193, Wallingford.

FOISSNER, W. \& PEER, T. (1985). Protozoologische Untersuchungen an Almböden im Gasteiner Tal (Zentralalpen, Österreich). In: Beiträge zu den Wechselbeziehungen zwischen Hochgebirgsökosystemen und dem Menschen (Ed. H. Franz), Veröffentlichungen des Österreichischen MaB-Programms, 9. Universitätsverlag Wagner, pp. 27-50, Innsbruck.

FRANZ, H. (1975). Die Bodenfauna der Erde in biozönotischer Betrachtung. Teil I. Wiesbaden.

FRANZ, H. (1980). The overall dynamics of the tested high mountain soils. Untersuchungen an alpinen Böden in den Hohen Tauern 1974-1978. In: Stoffdynamik und Wasserhaushalt (Ed. H. Franz), Veröffentlichungen des Österreichischen MaB-Hochgebirgsprogramms Hohe Tauern, 3. Universitätsverlag Wagner, pp. 287-295, Innsbruck.

FRANZ, H. (1981). Bodenbiologische Untersuchungen in den Hohen Tauern 19741978. Veröffentlichungen des Österreichischen MaB-Hochgebirgsprogramms Hohe Tauern, 4. Universitätsverlag Wagner, Innsbruck.

FRECKMAN, D. (Ed.) (1994). Life in Soil. Soil Biodiversity: Its Importance to Ecosystem Processes. Report of a Workshop Held at The Natural History Museum, 30. Aug. - 01. Sep. 1994 in London, 26 pp., Fort Collins, USA.

FREI, E. (1944). Morphologische, chemische und kolloidchemische Untersuchung subalpiner Weide- und Waldböden der Rendzina- und 
der Podzolserie. Berichte der Schweizerischen Botanischen Gesellschaft, 54: 267-346.

GAMS, W. (1959). Die Bodenpilze im Zentralalpinen Rohhumus. Diss. Univ. Innsbruck.

GEMESI, O., SKAMBRACKS, D. \& TOPP, W. (1995). Einfluß eines geregelten forstlichen Eingriffs auf die Besiedlungsdichte und den Streuabbau der Regenwürmer im Flynsch der Tegernseer Berge. Forstwissenschaftliches Centralblatt, 114: 272-281.

GERBER, K. (1985). Faunistische und ökologische Studie über die Nematoden einiger subalpiner Böden bei Badgastein (Zentralalpen, Österreich). In: Beiträge $z u$ den Wechselbeziehungen zwischen Hochgebirgsökosystemen und dem Menschen (Ed. H. Franz), Veröffentlichungen des Österreichischen MaB-Programms, 9. Universitätsverlag Wagner, pp. 113-131, Innsbruck.

GHILAROV, M.S. (1979). Soil fauna of Brown Soil in the Caucasus beech and fir mixed forests and some other communities. Pedobiologia, 19: 408-424.

GIGON, A. (1983). Typology and principles of ecological stability and instability. Mountain Research and Development, 3: 95-102.

GILOT, J.C. \& DOMMERGUES, Y. (1967). Note sur le lithosol calcaire à mor de la station subalpine de la R. C. P. 40. Revue d'Ecologie et de Biologie du Sol, 4: 357-383.

GILYASOVA, E.V. (1993). Pollution impact on soil mesofauna of Lapland biosphere reserve. In: Aerial Pollution in Kola Peninsula: Proceedings of the International Workshop, 14.-16. April 1992 in St. Petersburg (Ed. M.V. Kozlov, E. Haukioja \& V.T. Yarmishko), pp. 366-368, Apatity, Russia.

GISI, U., SCHENKER, R., SCHULIN, R., STADELMANN, F.X. \& STICHER, H. (1997). Bodenökologie. Thieme-Verlag, 350 pp., Stuttgart.

GISIN, H. (1957). Collembolen einiger Waldböden des Fuorngebietes (Schweizerischer Nationalpark). Ergebnisse der wissenschaftlichen Untersuchungen im Schweizer Nationalpark, 6: 109-114.

GLASSTETTER, M. (1991). Die Bodenfauna und ihre Beziehungen zum Nährstoffhaushalt in Geosystemen des Tafel- und Faltenjura (Nordwestschweiz). Physiogeographica. Basler Beiträge zur Physiogeographie, 15, 224 pp., Basel.

GÖBL, F. (1994). Forstliche Mykorrhizaforschung in Österreich. Mitteilungen der Österreichischen Bodenkundlichen Gesellschaft, 48/49: 325-337.

GOURBIÈRE, F. (1986). Méthode d'étude simultanée de la décomposition et des mycoflores des aiguilles de conifères (Abies alba). Soil Biology and Biochemistry, 18: 155-160.

GRABHERR, G. (1994). Biodiversität und landischaftliche Vielfalt Österreichs. In: Ökologische Grundwerte in Österreich - Modell für Europa? (Ed. W. 
Morawetz), Biosystematics and Ecology Series. Suppl. Österreichische Akademie der Wissenschaften., pp. 23-55, Wien.

GRACANIN, Z. (1970). Nutzung und Schutz von Böden aus Carbonatgestein im Bereich der alpinen Waldgrenze. Forstarchiv, 41: 169-173.

GREENLAND, D.J. \& SZABOLCS, I. (Eds.) (1994). Soil Resilience and Sustainable Land Use. CAB International, 561 pp., Wallingford.

GROOMBRIDGE, B. (Ed.) (1992). Global Biodiversity. Status of the Earth's Living Resources. Chapmann \& Hall, 306 pp., London.

GSTRAUNTHALER, G. \& SCHINNER, F. (1989). Bodenpilze in der alpinen, subalpinen und montanen Stufe in den hohen Tauern (Österreich). In: Struktur und Funktion von Graslandökosystemen im Nationalpark Hohe Tauern (Ed. A. Cernusca), Veröff. d. österr. MaB-Programms, 13. Universitätsverlag Wagner, pp. 227-232, Innsbruck.

GUISAN, A., HOLTEN, J.I., SPICHIGER, R. \& TESSIER, L. (Eds.) (1995). Potential Ecological Impacts of Climate Change in Alps and Fennoscandian Mountains. Publication hors-série no 8 des Conservatoire et Jardin botaniques de la Ville de Genève. 194 pp., Genève.

HABER, W., SPANDAU, L. \& TOBIAS, K. (1990). Ökosystemforschung Berchtesgaden. In: 1. Schlußbericht über die Arbeiten der Fachdisziplinen (Hauptphase), 2. Umweltqualitätsziele für den Alpen- und Nationalpark Berchtesgaden (Ed. Umweltbundesamt), Bonn.

HACKL, E., ZECHMEISTER-BOLTENSTERN, S. \& KANDELER, E. (1995). Denitrifikation und Stickstoffverlagerung von Almböden unterschiedlicher Nutzung. Mitteilungen der Deutschen Bodenkundlichen Gesellschaft, 76: 613-616.

HAGVAR, S. (1982). Collembola in Norwegian coniferous forest soils. I: Relations to plant communities and soil fertility. Pedobiologia, 24: 255-296.

HAGVAR, S. \& OSTBYE, E. (1975). Occurence and role of different invertebrate groups in alpine Salix herbacea snowbeds in Hardangervidda. In: Fennoscandian Tundra Ecosystems. Part 2 Animals and Systems Analysis (Ed. F.E. Wielgolaski), Ecological Studies, 17. Springer-Verlag, pp. 88-93, Heidelberg.

HANDSCHIN, E. (1919). Über die Collembolenfauna der Nivalstufe. Revue Suisse de Zoologie, 27: 65-98.

HANSSON, L. (1987). An interpretation of rodent dynamics as due to trophic interactions. Oikos, 50: 308-318.

HARSIA, T. (1995). Collembola communities from the Apuseni Mountains (the Carpathians). Bulletin Entomologique de Pologne, 64: 217-228.

HASELWANDTER, K. (1989). Die Mykotrophie alpiner Pflanzengesellschaften oberhalb der Waldgrenze mit besonderer Berücksichtigung der Mykorrhiza. In: Struktur und Funktion von Graslandökosystemen im Nationalpark Hohe 
Tauern (Ed. A. Cernusca), Veröffentlichungen des Österreichischen MaBProgramms, 13. Universitätsverlag Wagner, pp. 217-226, Innsbruck.

HASELWANDTER, K. \& READ, D.J. (1980). Fungal associations of roots of dominant and sub-dominant plants in high-alpine vegetation systems with special reference to mycorrhiza. Oecologia, 45: 57-62.

HAUNOLD, E., GLUDOVATZ, A. \& RICHTER, E. (1980). Stickstoffdynamik in einem alpinen Pseudogley unter Curvuletum. In: Untersuchungen an alpinen Böden in den Hohen Tauern 1974-1978. Stoffdynamik und Wasserhaushalt (Ed. H. Franz), Veröffentlichungen des Österreichischen MaB-Hochgebirgsprogramms Hohe Tauern, 3. Universitätsverlag Wagner, pp. 131-153, Innsbruck.

HAWKSWORTH, D.L. (Ed.) (1991). The Biodiversity of Microorganisms and Invertebrates: Its Role in Sustainable Agriculture. CAB International, 302 pp., Wallingford.

HAWKSWORTH, D.L. (1992). Litmus tests for ecosystem health: the potential of bioindicators in the monitoring of biodiversity. In: Biodiversity. Implications for Global Food Security (Eds. M.S. Swaminathan \& S. Jana), pp. 184-204, Madras.

HAWKSWORTH, D.L. \& COLWELL, R.R. (1992). Microbial Diversity 21: biodiversity amongst microorganisms and its relevance. Biodiversity and Conservation, 1: 221-226.

HAWKSWORTH, D.L. \& RITCHIE, J.M. (1993). Biodiversity and Biosystematic Priorities: Microorganisms and Invertebrates. Priorities for Biosystematic Research in Support of Biodiversity in Developing Countries: Microorganisms and Invertebrates. CAB International, $120 \mathrm{pp}$., Wallingford.

HEAL, O.W., STRUWE, S. \& KJOLLER, A. (1996). Diversity of soil biota and ecosystem function. In: Global Change and Terrestrial Ecosystems (Eds. B. Walker \& W. Steffen), International Geosphere-Biosphere Programme Book Series 1. Cambridge University Press, pp. 385-402, Cambridge.

HEAL, O.W., BROLL, G., HOOPER, D.U., MCCONNELL, J., WEBB, N.R. \& WOOKEY, P.A. (1998). Impacts of global change on tundra soil biology. In: Global Change in Europe's Cold Regions (Eds. O.W. Heal, T.V. Callaghan, J.H.C. Cornelissen, C. Körner \& S.E. Lee), European Commission Ecosystem Research Report, 27, pp. 65-134, Luxembourg.

HENTTONEN, H. (1995). Climate change and the ecology of alpine mammals. In: Potential ecological impacts of climate change in Alps and Fennoscandian mountains (Eds. A. Guisan, J.I. Holten, R. Spichiger \& L. Tessier), Publication hors-série no 8 des Conservatoire et Jardin botaniques de la Ville de Genève, pp. 75-78, Genève. 
HERBERT, R.A. \& CODD, G.A. (Eds.) (1986). Microbes in Extreme Environments. Academic Press, 329 pp., London.

HERRERO, J., GARCÍA-GONZÁLEZ, R. \& GARCÍA-SERRANO, A. (1994). Altitudinal distribution of alpine Marmot (Marmota marmota) in the Pyrenees, Spain/France. Arctic and Alpine Research, 26: 328-331.

HERSHEY, A.E., MERRITT, R.W. \& MILLER, M.C. (1995). Insect diversity, life history, and trophic dynamics in arctic streams, with particular emphasis on black flies (Diptera: Simuliidae). In: Arctic and Alpine Biodiversity: Patterns, Causes and Ecosystem Consequences (Eds. F.S. Chapin III \& C. Körner), Ecological Studies, 113. Springer-Verlag, pp. 283-295, Heidelberg.

HEYWOOD, V.H. \& WATSON, R.T. (Eds.) (1995). Global Diversity Assessment. Cambridge University Press, 1130 pp., Cambridge.

HOBBIE, S.E. (1995). Direct and indirect effects of plant species on biogeochemical processes in arctic ecosystems. In: Arctic and Alpine Biodiversity: Patterns, Causes and Ecosystem Consequences (Eds. F.S. Chapin III \& C. Körner), Ecological Studies 113. Springer-Verlag, pp. 213-224, Heidelberg.

HODKINSON, I.D., COULSON, S.J., WEBB, N.R. \& BLOCK, W. (1996). Can high Arctic soil microarthropods survive elevated summer temperatures? Functional Ecology, 10: 314-321.

HODKINSON, I.D., WEBB, N.R., BALE, J.S., BLOCK, W., COULSON, S.J. \& STRATHDEE, A.T. (1998). Global change and Arctic ecosystems: conclusions and predictions from experiments with terrestrial invertebrates on Spitsbergen. Arctic and Alpine Research, 30: 306-313.

HOLE, F.D. (1981). Effects of animals on soil. Geoderma, 25: 75-112.

HOLTEN, J.I., PAULSEN, G. \& OECHEL, W.C. (Eds.) (1993). Impacts of Climatic Change on Natural Ecosystems with Emphasis on Boreal and Arctic/Alpine Areas. Norwegian Institute for Nature Research (NINA) and the Directorate for Nature Management (DN), pp. 185, Trondheim, Norway.

HOLTMEIER, F.-K. (1994). Ecological aspects of climatically-caused timberline fluctuations. Review and outlook. In: Mountain Environments in Changing Climates (Ed. M. Beniston), pp. 220-233, London.

HOLTMEIER, F.-K. \& BROLL, G. (1992). The influence of tree islands and microtopography on pedoecological conditions in the forest-alpine tundra ecotone on Niwot-Ridge, Colorado Front Range, USA. Arctic and Alpine Research, 24: 216-228.

HUNTLY, N. \& INOUYE, R. (1988). Pocket gophers in ecosystems: patterns and mechanisms. Pocket gophers profoundly affect microtopography, soils, plants and other animals. BioScience, 38: 786-793.

HUSTON, M.A. (1994). Biological Diversity. The Coexistence of Species on Changing Landscapes. Cambridge University Press, 681 pp., Cambridge. 
IVES, J. (1992). Institutional frameworks for the study of mountain environments and development. GeoJournal, 27: 127-129.

IVES, J.D. \& MESSERLI, B. (1984). Stability and instability of mountain ecosystems. Lessons learned and recommendations for the future. Mountain Research and Development, 4: 63-71.

JAHN, E. (1960). Ergebnisse von Bodentieruntersuchungen an der Waldund Baumgrenze bei Obergurgl. Centralblatt für das gesamte Forstwesen, 77: 26-51.

JANETSCHEK, H. (1949). Tierische Successionen auf hochalpinem Neuland. Nach Untersuchungen am Hintereis-, Niederjoch- und Gepatschferner in den Ötztaler Alpen. Berichte der naturwissenschaftlich-medizinischen Vereinigung Innsbruck, 48/49, 1-215.

JANETSCHEK, H. (1993). Über Wirbellosen-Faunationen in Hochlagen der Zillertaler Alpen. Berichte der naturwissenschaftlich-medizinischen Vereinigung Innsbruck, 80: 121-165.

JANETSCHEK, H., MEYER, E., SCHATZ, H. \& SCHATZ-DE ZORDO, I. (1987). Ökologische Untersuchungen an Wirbellosen im Raum Gurgl unter Berücksichtigung anthropogener Einflüsse. In: MaB-Projekt Obergurgl (Ed. G. Patzelt), Veröffentlichungen des Österreichischen MaBProgramms, 10. Universitätsverlag Wagner, pp. 281-315, Innsbruck.

JENNY, H. (1980). The Soil Resource. Origin and Behavior. Ecological Studies, 37. Springer-Verlag, 377 pp., Heidelberg.

JÖRGENSEN, M. (1934). A quantitative investigation of the microfauna communities of the soils in East Greenland. Meddelser om Gronland, 100 (9). Kopenhagen.

KEPLIN, B. (1994). Influence of the soil mosaic on biodiversity at heath sites in the European subarctic - Investigations on soil mesofauna. Transactions 15th World Congress of Soil Science (Mexico), 4b: 164-165.

KÖGEL, I. (1987). Organische Stoffgruppen in Waldhumusformen und ihr Verhalten während der Streuzersetzung und Humifizierung. Bayreuther Bodenkundliche Berichte, 1 . Bayreuth.

KÖGEL, I., ZIEGLER, F. \& ZECH, W. (1988). Lignin signature of subalpine Rendzinas (Tangel- and Moderrendzina) in the Bavarian Alps. Zeitschrift für Pflanzenernährung und Bodenkunde, 151: 15-20.

KONEVA, G.G. (1993). Changes in soil macrofauna around "Severonikel» smelter complex. In: Aerial Pollution in Kola Peninsula: Proceedings of the International Workshop, 14.-16. April 1992 in St. Petersburg (Eds. M.V. Kozlov, E. Haukioja \& V.T. Yarmishko), pp. 362-364, Apatity, Russia.

KOPONEN, S. (1984). Invertebrates of Inari Lapland: introduction and study area. Kevo Notes, 7: 3-9. 
KOPONEN, S. \& OJALA, M.-L. (1975). Quantitative study of invertebrate groups in the soil and ground layer of IBP sites at Kevo, northern Finland. Reports from the Kevo Subarctic Research Station, 12: 45-52.

KUBIENA, W.. (1943). Beiträge zur Bodenentwicklungslehre: Entwicklung und Systematik der Rendsinen. Bodenkunde und Pflanzenernährung, 29: 108119.

KÜBELBÖCK, G. \& MEYER, E. (1981). Ökologische Untersuchungen an Wirbellosen des zentralalpinen Hochgebirges (Obergurgl, Tirol) VI. Abundanz und Biomasse der Oligochaeta (Lumbricidae, Enchytraeidae). Alpin-Biologische Studien der Universität Innsbruck, 15: 1-52.

KÜHNELT, W. (1944). Über Beziehungen zwischen Tier- und Pflanzengesellschaften. Biologia Generalis, 17: 566-593.

KURCHEVA, G.F. (1972). Soil invertebrates in forests of the Transcarpathiens. Pedobiologia, 12: 381-400.

KYTÄVIITA, M.-M., FRITZE, H. \& NEUVONEN, S. (1990). The effects of acidic irrigation on soil microorganisms at Kevo, northern Finland. Environmental Pollution, 66: 21-31.

LAVELLE, P., LATTAUD, C., TRIOGO, D. \& BAROIS, I. (1995). Mutualism and biodiversity in soils. In: The Significance and Regulation of Soil Biodiversity. Proceedings of the International Symposium on Soil Biodiversity, Michigan State University, May 3-6 1993 (Eds. H.P. Collins, G.P. Robertson \& M.J. Klug), Kluwer, pp. 23-33, Dordrecht.

LEE, K.E. (1991): The diversity of soil organisms. In: The Biodiversity of Microorganisms and Invertebrates: Its Role in Sustainable Agriculture. Proceedings of the First Workshop on the Ecological Foundations of Sustainable Agriculture (WEFSA 1): London, 26-27 July 1990 (Ed. D.L. Hawksworth), pp. 73-87, Wallingford.

LEE, K.E. (1994). The functional significance of biodiversity in soils. Transactions 15th World Congress of Soil Science (Mexico), 4a: 168-181.

LEGAKIS, A. (1986). Comparative study of the soil arthropods of three ecosystems on Mount Hymettos (Attica, Greece). Biologia Gallo-hellenica, 12: 371-375.

LESER, H. (1994). Das Biodiversitätsprojekt auf der Nenzlinger Weide. Regio Basiliensis, 35: 81-90.

LIENHARD, C. (1980). Zur Kenntnis der Collembolen eines alpinen Caricetum firmae im Schweizerischen Nationalpark. Pedobiologia, 20: 369-386.

MANI, M.S. (1968). Ecology and Biogeography of High Altitude Insects. Junk, 527 pp., The Hague.

MARTINUCCI, G. \& SALA, G. (1979). Lumbricids and soil types in prealpine and alpine woods. Boll. Zool., 46: 279-297. 
McCOY, E.D. (1990). The distribution of insects along elevational gradients. Oikos, 58: 313-322.

MEADOWS, P.S. \& MEADOWS, A. (Eds.) (1991). The. Environmental Impact of Burrowing Animals and Animal Burrows, Symposia of the Zoological Society of London, 63. Clarendon Press, 349 pp., Oxford.

MEYER, E. (1981). Abundanz und Biomasse von Invertebraten in zentralalpinen Böden (Hohe Tauern, Österreich). Iṇ: Bodenbiologische Untersuchungen in den Hohen Tauern 1974-1978 (Ed. H. Franz), Veröffentlichungen des Österreichischen MaB-Hochgebirgsprogramms Hohe Tauern, 4. Universitätsverlag Wagner, pp. 153-178, Innsbruck.

MEYER, E. (1985). Distribution, activity, life-history and standing crop of Julidae (Diplopoda, Myriapoda) in the Central High Alps (Tyrol, Austria). Holarctic Ecology, 18: 141-150.

MEYER, E. (1993). Beeinflussung der Fauna alpiner Böden durch Sommer- und Wintertourismus in West-Österreich. Revue Suisse de Zoologie, 100: 519-527.

MEYER, E. \& EISENBEIS, G. (1985). Water relations in millipedes from some alpine habitat types (Central Alps, Tirol) (Diplopoda). Bijdragen tot de Dierkunde, 55: 131-142.

MEYER, E. \& THALER, K. (1995). Animal diversity at high altitudes in the Austrian Central Alps. In: Arctic and Alpine Biodiversity: Patterns, Causes and Ecosystem Consequences (Eds. F.S. Chapin III \& C. Körner), Ecological Studies, 113. Springer-Verlag, pp. 97-110, Heidelberg.

MOEN, J., LUNDBERG, P.A. \& OKSANEN, L. (1993). Lemming grazing on snowbed vegetation during a population peak, Northern Norway. Arctic and Alpine Research, 25: 130-135.

MOLDENKE, A.R., BAUMEISTER, N., ESTRADA-VENEGAS, E. \& WERNZ, J. (1994). Linkages between soil biodiversity and above-ground plant performance. Transactions 15th. World Congress of Soil Science (Mexico), 4a: 186-204.

MOSER, M., HOFMANN, J., PFITSCHER, A., RIDL, W. \& WIESER, R. (1987). Mikrobielle Parameter als Indikatoren für die anthropogene Beeinflussung alpiner Böden, besonders durch Massentourismus. In: MaB-Projekt Obergurgl (Ed. G. Patzelt), Veröffentlichungen des Österreichischen MaB-Programms, 10. Universitätsverlag Wagner, pp. 257-279, Innsbruck.

MOSIMANN, T. (1985). Untersuchungen zur Funktion subarktischer und alpiner Geoökosysteme, Finnmark (Norwegen). und Schweizer Alpen. Basler Beiträge zur Physiogeographie 7, 488 pp., Basel.

MÜLLER, G., KEPLIN, B. \& BROLL, G. (1994). Erprobung des Köderstreifentests auf nährstoffarmen Böden an der polaren Waldgrenze in Nord-Finnland. Braunschweiger Naturkundliche Schriften, 4: 665-669. 
MÜLLER-HOHENSTEIN, K. (Ed.) (1974). International Workshop on the Development of Mountain Environments, Dec. 1974, Final Report. German Foundation of International Development, 208 pp., München.

NAEEM, S., THOMPSON, L.J., LAWLER, S.P., LAWTON, J.H. \& WOODFIN, R.M. (1994). Declining biodiversity can alter the performance of ecosystems. Nature, 368: 734-737.

NAKOS, G. (1984). Nitrification activity in pseudoalpine grassland soils: evidence of adaptation to low temperature. Soil Biology and Biochemistry, 16: 85-86.

NEUVONEN, S. \& SUOMELA, J. (1990). The effect of simulated acid rain on pine needle and birch leaf litter decomposition. Journal of Applied Ecology, 27: 857-872.

NEUWINGER, I. (1987). Bodenökologische Untersuchungen im Gebiet Obergurgler Zirbenwald - Hohe Mut. In: MaB-Projekt Obergurgl (Ed. G. Patzelt), Veröffentlichungen des Österreichischen MaB-Programms, 10. Universitätsverlag Wagner, pp. 173-190, Innsbruck.

NOSEK, J. (Ed.) (1986). The Soil Fauna of the Little Carpathians. Slovak Acadamy of Sciences, 359 pp., Bratislava.

NURMINEN, M. (1965a). Enchytraeid and Lumbricid records (Oligochaeta) from Spitsbergen. Annales Zoologici Fennici, 2: 1-10.

NURMINEN, M. (1965b). Enchytraeids (Oligochaeta) from Northern Norway and western Lapland. Annales Zoologici Fennici, 2: 11-16.

NURMINEN, M. (1977). Enchytraeidae (Oligochaeta) from the Großglockner region of the Austrian Alps. Annales Zoologici Fennici, 14: 224-227.

OZENDA, P. \& BOREL, J.L. (1991). Les conséquences écologiques possibles des changements climatiques dans l'arc alpin, Rapport Futuralp 1. ICALPE, 49 pp., Grenoble.

PASTOR, J. (1995). Diversity of biomass and nitrogen distribution among plant species in arctic and alpine tundra ecosystems. In: Arctic and Alpine Biodiversity: Patterns, Causes and Ecosystem Consequences (Eds. F.S. Chapin III \& C. Körner), Ecological Studies, 113. Springer-Verlag, pp. 255-270, Heidelberg.

PERTY, M. (1849). Mikroskopische Organismen der Alpen und der italienischen Schweiz. Mitteilungen der Naturforschenden Gesellschaft Bern: 153-176.

POP, V.V. (1987). Density and biomass of earthworm synusia in forest ecosystems of the Romanian Carpathians. In: On Earthworms (Eds. A.M. Bonvicini Pagliai \& P. Omodeo), Selected Symposia and Monographs U.Z.I., 2, Mucchi, Modena 1987, pp. 183-190.

POP, V.V. \& VASU, A. (1995). Conspicuous vermic characters in mountain soils developed by large lumbricids (Oligochaeta). Acta Zoologica Fennica, 196: 83-86. 
POPOVICI, I. (1984). Nematode abundance, biomass and production in a beech forest ecosytem. Pedobiologia, 26: 205-219.

PORNON, A. \& DOCHÉ, B. (1994). Dynamics and functioning of Rhododendron ferrugineum subalpine heathlands (Northern Alps, France). Mineral nitrogen availability in the context of global climate change. In: Mountain Environments in Changing Climates (M. Beniston), Routledge, pp. 244-258, London.

PRICE, M.F. (1995). Mountain Research in Europe: An Overview of MAB Research from the Pyrenees to Sibiria. Man and Biosphere Series, 14. UNESCO and the Parthenon Publishing Group, 230 pp., Paris.

RANGGER, A., INSAM, H. \& HASELWANDTER, K. (1994). Mikrobielle Aktivitäten und Biomasse entlang eines Höhengradienten in den nördlichen Kalkalpen. Mitteilungen der Österreichischen Bodenkundlichen Gesellschaft, 48/49: 379-386.

REHDER, H. \& SCHÄFER, A. (1978). Nutrient turnover studies in alpine ecosystems. IV. Communities in the Central Alps and comparative survey. Oecologia, 34: 309-327.

REUTIMANN, P. (1987). Quantitative aspects of the feeding activity of some oribatid mites (Oribatida, Acari) in an alpine meadow ecosystem. Pedobiologia, 30: 425-433.

REYNOLDS, J.F. \& TENHUNEN, J.D. (1996). Landscape Function and Disturbance in Arctic Tundra. Ecological Studies, 120. Springer-Verlag, pp. 437, Berlin.

RIBIAUCOURT, E. DE (1896). Etude sur la faune lombricide de la Suisse. Revue Suisse de Zoologie, 4: 1-110.

RICHARD, P.W. \& HARMSTON, F.C. (1972). Diptera and other arthropods of the Sukkertoppen Tasersiaq Area, Southwest Greenland. Arctic, 25: $107-114$

ROBINSON, C.H. \& WOOKEY, P.A. (1997). Microbial ecology, decomposition and nutrient cycling. In: Ecology of Arctic Environments (Eds. S.J. Woodin \& M. Marquiss), Special Publication Series of the British Ecological Society 13, Blackwell, pp. 41-68, Oxford.

RÖMER, F. \& SCHAUDINN, F. (Eds.) (1900). Fauna Arctica. Eine Zusammenstellung der arktischen Tierformen mit besonderer Berücksichtigung des Spitzbergen-Gebietes auf Grund der Ergebnisse der Deutschen Expedition in das Nördliche Eismeer im Jahre 1898. Band 1. Jena.

ROSA, D. (1887). La distribuzione verticale dei lombrichi sulle Alpi. Boll. Musei Zool. Anat. comperata Torino, 2: 31.

ROSSWALL, T. \& HEAL, O.W. (Eds.) (1975). Structure and Function of Tundra Ecosystems. Ecological Bulletins, 20. Swedish. Natura, Science Research Council, 450 pp., Stockholm. 
ROSSWALL, T., VEUM, A.K. \& KÄRENLAMPI, L. (1975). Plant litter decomposition at Fennoscandian Tundra sites. In: Fennoscandian Tundra Ecosystems. Part 1: Plants and Microorganisms (Ed. F.E. Wielgolaski), Ecological Studies, 16. Springer-Verlag, pp. 268-278, Heidelberg.

ROUNSEVELL, M.D.A. \& LOVELAND, P.J. (Eds.) (1994). Soil Responses to Climate Change. Proceedings of the NATO Advanced Research Workshop on Soil Responses to Climatic Change. Springer-Verlag, 312 pp., Berlin.

RÜPPELL, G. (1968). Über Ökologie und Tagesrhythmus von Bodenarthropoden eutrophierter Tundragebiete Westspitzbergens. Pedobiologia, 8: 150-157.

RUSEK, J., UUHELOVA, B. \& UNAR, J. (1975). Soil biological features of some alpine grasslands in Czechoslovakia. In: Progress in Soil Biology (Ed. J. Vanek), Junk, pp. 199-215, The Hague.

RUZICKA, V. \& ZACHARDA, M. (1994). Arthropods of stony debris in the Krkonose Mountains, Czech Republic. Arctic and Alpine Research, 26: 332-338.

SAMEDOV, N.G. \& BABABEKOVA, L.A. (1980). Landscape variations of mesopopulation amount and biomass in soils of Minor Caucasus region in Azerbaijan. Pedobiologia, 20: 387-393.

SCHALLER, F. (1994). Bodenzoologie in Österreich. Mitteilungen der Österreichischen Bodenkundlichen Gesellschaft, 48/49: 19-26.

SCHATZ, H. (1981). Abundanz, Biomasse und Respirationsrate der Arthropoden-Mesofauna im Hochgebirge (Obergurgl, Tiroler Zentralalpen). Pedobiologia, 22: 52-70.

SCHIMEL, J. (1995). Ecosystem consequences of microbial diversity and community structure. In: Arctic and Alpine Biodiversity: Patterns, Causes and Ecosystem Consequences (Eds. F.S. Chapin III \& C. Körner), Ecological Studies, 113. Springer-Verlag, pp. 239-254, Heidelberg.

SCHINNER, F. (1982). Soil microbial activities and litter decomposition related to altitude. Plant and Soil, 65: 87-94.

SCHINNER, F. (1983). Litter decomposition, $\mathrm{CO}_{2}$-release and enzyme activities in a snowbed and on a windswept ridge in an alpine environment. Oecologia, 59: 288-291.

SCHINNER, F. \& GURSCHLER, A. (1989). Bakterien-, Hefen-, und ATPGehalte von Böden entlang einem Höhentransekt in den Hohen Tauern. In: Struktur und Funktion von Graslandökosystemen im Nationalpark Hohe Tauern (Ed. A. Cernusca), Veröffentlichungen des Österreichischen MaBProgramms, 13. Universitätsverlag Wagner, pp. 233-237, Innsbruck.

SCHINNER, F., NIEDERBACHER, R. \& RAINER, J. (1989). Enzymaktivitäten und $\mathrm{CO}_{2}$-Freisetzung von Bodenmaterialien entlang einem Höhentransekt in den Hohen Tauern. In: Struktur und Funktion von Graslandökosystemen im 
Nationalpark Hohe Tauern (Ed. A. Cernusca), Veröffentlichungen des Österreichischen MaB-Programms, 13. Universitätsverlag Wagner, pp. 239-247, Innsbruck.

SCHULZE, E.-D. \& MOONEY, H.A. (Eds.) (1993). Biodiversity and Ecosystem Function. Ecological Studies, 99. Springer-Verlag, 519 pp., Heidelberg.

SCHWEIZER, J. (1961). Die Landmilben der Schweiz (Mittelland, Jura, Alpen): Publisher 378 pp., Zürich.

SELLNICK, G. (1940). Die Milbenfauna Islands. Göteborgs $k$. vetensk. o. vittersh samh. Handbl. Ser. B, 6 (14): 1-130.

SENICZAK, S. \& PLICHTA, W. (1978). Structural dependence of moss mite populations (Acari, Oribatei) on patchiness of vegetation in moss-lichentundra at the north coast of Hornsund, West Spitsbergen. Pedobiologia, 18: $145-152$.

SIMÓN, M., GARCÍA, I., GIL, C. \& POLO, A. (1994). Characteristics of the organic matter of Mediterranean high-mountain soils. Geoderma, 61: 119-131.

SINNIGE, N., TAMIS, W. \& KLIJN, F. (1992). Indeling van Bodemfauna in ecologische Soortgroepen. Centrum voor Milieukunde, Rijksuniversiteit Leiden Report, 80.

SISTANI, N. (1980). Einfluß von Regenwürmern auf die Entstehung von organischen und anorganischen Neubildungen im Boden. In: Untersuchungen an alpinen Böden in den Hohen Tauern 1974-1978. Stoffdynamik und Wasserhaushalt (Ed. H. Franz), Veröffentlichungen des Österreichischen MaB-Hochgebirgsprogramms Hohe Tauern, 3. Universitätsverlag Wagner, pp. 155-177, Innsbruck.

SKAMBRACKS, D. (1996). Die Bedeutung saprophager Regenwürmer im Nährstoffkreislauf von Waldböden. Dissertation. Universität Köln.

SOLBRIG, O.T., EMDEN, H.M. \& OORDT, P.G.W.J. VAN (Eds.) (1994). Biodiversity and Global Change. CAB International, 227 pp., Wallingford.

SOLHØY, T. (1975). Dynamics of Enchytraeidae populations on Hardangervidda. In: Fennoscandian Tundra Ecosystems. Part 2 Animals and Systems Analysis (Ed. F.E. Wiegolaski), Ecological Studies, 17. SpringerVerlag, pp. 55-59, Heidelberg.

SOLHØY, T. \& KOPONEN, S. (1981). Oribatei fauna (Acari) on alpine heath at Kevo, Finland. Reports from the Kevo Subarctic Research Station, 17: 41-43.

SOMBROEK, W.G. (1994). Foreword - soils and biodiversity. Transactions 15th World Congress of Soil Science (Mexico), 4a: 165-167.

SØMME, L. (1993). Effects on boreal and arctic/alpine fauna. In: Impacts of Climatic Change on Natural Ecosystems, with Emphasis on Boreal and Arctic/Alpine Areas (Eds. J.I. Holten, G. Paulsen \& W.C. Oechel), Norwegian Institute for Nature Research (NINA) and the Directorate for Nature Management (DN), pp. 172-185, Trondheim, Norway. 
SØMME, L. (1995). Invertebrates in Hot and Cold Arid Environments. SpringerVerlag, pp. 275, Heidelberg.

STRIGANOVA, B.R. (1975). Dispersion patterns of diplopods and their activity in the litter decomposition in the Carpathian foothills. In: Progress in Soil Zoology (Ed. W. Junk), B.V. Academia, pp. 167-172, Prag.

STRIGANOVA, B.R. \& MAZANTSEVA, G.P. (1979). Age and size structure of a population of Pachyiulus foetidissimus (Diplopoda) in the Caucasus. Oikos, 32: 416-421.

SVEUM, P. (1986). The influence of grazing by Hypogastrura viatica (Insecta: Collembola) on microbial activity in decomposing kelp on Spitsbergen. Polar Research, 5: 71-77.

SVOBODA, J. \& FREEDMAN, B. (Eds.) (1992). Ecology of a Polar Oasis. Alexandra Fiord, Ellesmere Island, Canada. Captus Press, 268 pp., Ontario.

SZABÓ, I.M. (1974). Microbial Communities in a Forest-Rendzina Ecosystem. Akadémiai Kiadó, 415 pp., Budapest.

TAPPEINER, U. \& CERNUSCA, A. (1994). Bestandesstruktur, Energiehaushalt und Bodenatmung einer Mähwiese, einer Almweide und einer Almbrache. Verhandlungen der Gesellschaft für Ökologie, 23: 49-56.

THALER, K., KNOFLACH, B. \& MEYER, E. (1993). Fragmenta Faunistica Tirolensia X. Arachnida, Acari: Caeculidae; Myriapoda: Diplopoda; Insecta, Nematocera: Limoniidae, Sciaridae. Berichte des naturwissenschaftlich-medizinischen Vereins Innsbruck, 80: 311-325.

THALER, K., DE ZORDO, I., MEYER, E., SCHATZ, H. \& TROGER, H. (1978). Arthropoden auf Almflächen im Raum von Badgastein (Zentralalpen, Salzburg, Österreich). In: Ökologische Analysen von Almflächen im Gasteiner Tal (Ed. A. Cernusca), Veröffentlichungen des Österreichischen MaBHochgebirgsprogramms Hohe Tauern, 2. Universitätsverlag Wagner, pp. 195-233, Innsbruck.

TOPP, W. (1975). Biozönotische Untersuchungen in einem Kar der östlichen Hohen Tauern. Carinthia II, 85: 275-284.

TOSCA, C. (1986). Le cycle de l'azote dans les milieux supra-forestiers des Pyrénées Centrales: minéralisation de l'azote dans les sols des pelouses subalpines. Oecologia Plantarum, 7: 57-73.

TRÄGARDH, I. (1910). Acariden aus dem Sarekgebirge. Naturwissenschaftliche Untersuchungen des Sarekgebirges in Schwedisch-Lappland 4. Stockholm.

TROCKNER, V. \& KOPESZKI, H. (1994). Auswirkungen der künstlichen Beschneiung auf Bodenverdichtung, Bodentemperatur, Ernteertrag und Collembolenfauna von Pistenböden. Verhandlungen der Gesellschaft für Ökologie, 23: 283-288. 
TROGER, H. (1981). Untersuchungen zur Dynamik von Dipterenlarven in zentralalpinen Böden (Hohe Tauern, Österreich). In: Bodenbiologische Untersuchungen in den Hohen Tauern 1974-1978 (Ed. H. Franz), Veröffentlichungen des Österreichischen MaB-Hochgebirgsprogramms Hohe Tauern, 4. Universitätsverlag Wagner, pp. 179-190, Innsbruck.

TRÜPER, H.G. (1992). Prokaryotes: an overview with respect to biodiversity and environmental importance. Biodiversity and Conservation, 1: 227-236.

UNCED (1992). AGENDA 21. United Nations. Rio de Janeiro.

UNEP (1980). The Major Problems of Man and Environment Interactions in Mountain Ecosystems: A Review. UNEP Report No. 2. United Nations Environment Programme. Nairobi.

VÄRE, H., VESTBERG, M. \& EUROLA, S. (1992). Mycorrhiza and rootassociated fungi in Spitsbergen. Mycorrhiza, 1: 93-104.

VERHOEFF, K.W. (1896). Über Diplopoden Tirols, der Ostalpen und anderer Gegenden Europas, nebst vergleichend-morphologischen und biologischen Beobachtungen. (Beiträge zur Kenntnis paläarktischer Myriapoden 19). Arch. Naturg., 67: 221-240.

VERHOEFF, K.W. (1932). Zur Geographie, Ökologie und Systematik der Diplopoden Nordwestitaliens. Arch. Naturg. N. F., 1: 517-645.

WALKER, D. (1989). Diversity and stability. In: Ecological Concepts (Ed. J.M. Cherrett), Blackwell, pp. 115-145, Oxford.

WALLWORK, J.A. (1976a). The Distribution and Diversity of Soil Fauna. Academic Press, 355 pp., London.

WALLWORK, J.A. (1976b). The soil fauna of deserts: cold deserts. In: The Distribution and Diversity of Soil Fauna (Ed. J.A. Wallwork), Acad. Press, pp. 291-310, London.

WASILEWSKA, L. (1974). Analysis of the pasture ecosystem in Pieniny Mountains. XV.Quantitative distribution and respiratory metabolism with suggestion on production of nematodes on mountain pastures. Ekol. Pol., 22: 651-668.

WATSON, T.W., ZINYOWERA, M.C., MOSS, R.H. \& DOKKEN, D.J. (Eds.) (1996). Climate Change 1995. Impacts, Adaptions and Mitigation of Climate Change: Scientific-Technical Analyses. Cambridge University Press, 265 pp., Cambridge.

WIELGOLASKI, F.E. (Ed.) (1975a). Fennoscandian Tundra Ecosystems. Part 1 Plants and Microorganisms. Ecological Studies, 16. Springer-Verlag, Heidelberg.

WIELGOLASKI, F.E. (Ed.) (1975b). Fennoscandian Tundra Ecosystems. Part 2 Animals and Systems Analysis. Ecological Studies, 17. Springer-Verlag, Heidelberg.

WÜTHRICH, C. (1994). Die biologische Aktivität arktischer Böden mit spezieller Berïcksichtigung ornithogen eutrophierter Gebiete (Spitzbergen und Finnmark): Basler Beiträge zur Physiogeographie, 17. Basel. 
WÜTHRICH, C., DÖBELI, C., SCHAUB, D. \& LESER, H. (1994). The pattern of carbon-mineralization in the high-arctic Tundra (Western and Northern Spitsbergen) as an expression of landscape ecologic environment heterogeneity. Zeitschrift für Geomorphologie N. F. Supplement, 97: 251-264.

ZICSI, A. (1981). Regenwürmer des Glocknergebietes. In: Bodenbiologische Untersuchungen in den Hohen Tauern 1974-1978 (Ed. H. Franz), Veröffentlichungen des Österreichischen MaB-Hochgebirgsprogramms Hohe Tauern, 4. Universitätsverlag Wagner, pp. 91-94, Innsbruck.

ZÖTTL, H. (1965). Zur Entwicklung der Rendzinen in der subalpinen Stufe. II. Chemisch-biologische Dynamik. Zeitschrift für Pflanzenernährung, Düngung und Bodenkunde, 110: 115-126.

ZVYAGINTSEV, D.G., DOBROVOL'SKAYA, T.G., BAB'YEVA, I.P., ZENOVA, G.M., LYSAK, L.V. \& MARFENINA, O.Y. (1992). Role of microorganisms in the biogeocenotic functions of soils. Soviet Soil Science, 24: 63-77. 